\title{
Article \\ The Impact of Administrative Partitioning on the Regional Effectiveness of Forest Pest Management in Protected Area-Centered Ecosystems
}

\author{
Bri Tiffany ${ }^{1}$, Todd Chaudhry ${ }^{2}\left(\right.$, Richard W. Hofstetter ${ }^{3}\left(\mathbb{D}\right.$ and Clare Aslan ${ }^{1, *}$ \\ 1 School of Earth and Sustainability, Northern Arizona University, Flagstaff, AZ 86011, USA; bjt236@nau.edu \\ 2 Colorado Plateau Cooperative Ecosystem Studies Unit, National Park Service, Flagstaff, AZ 86011, USA; \\ todd.chaudhry@nau.edu \\ 3 School of Forestry, Northern Arizona University, Flagstaff, AZ 86011, USA; rich.hofstetter@nau.edu \\ * Correspondence: clare.aslan@nau.edu
}

check for

updates

Citation: Tiffany, B.; Chaudhry, T.;

Hofstetter, R.W.; Aslan, C. The

Impact of Administrative

Partitioning on the Regional

Effectiveness of Forest Pest

Management in Protected

Area-Centered Ecosystems. Forests

2022, 13, 395. https://doi.org/

$10.3390 /$ f13030395

Academic Editor: Angus Carnegie

Received: 22 January 2022

Accepted: 24 February 2022

Published: 28 February 2022

Publisher's Note: MDPI stays neutral with regard to jurisdictional claims in published maps and institutional affiliations.

Copyright: (c) 2022 by the authors. Licensee MDPI, Basel, Switzerland. This article is an open access article distributed under the terms and conditions of the Creative Commons Attribution (CC BY) license (https:// creativecommons.org/licenses/by/ $4.0 /)$.

\begin{abstract}
Research Highlights: Forest pest outbreaks that cross jurisdictional boundaries pose particular challenges, since both ecological and social factors influence the effectiveness of management responses. This study found that difficulties emerge from the misalignment of management objectives and policies that deter collaboration. The sharing of resources and collaborative responses to outbreaks may improve management outcomes. Background and Objectives: This study examines if and how boundaries influence the effectiveness of forest pest management within the protected area-centered ecosystems of Rocky Mountain National Park and Grand Canyon National Park, USA. Materials and Methods: Using semi-structured interviews and a survey distributed to forest managers, we explored how partitioning affects pest management effectiveness and identified barriers to and strategies for managing outbreaks that cross boundaries. Results: Cross-boundary outbreaks are uniquely challenging due to federally mandated policies, agency mission misalignment, a lack of formal collaboration, and a lack of public support for timber management programs. Strategies that may improve outcomes include reevaluating problematic policies; ensuring messaging is consistent across agencies; and developing a preventative cross-boundary forest insect outbreak management team. Conclusions: Measures to increase collaboration in multi-jurisdictional landscapes will help managers prepare for future forest pest outbreaks, which are expected to increase in frequency with climate change.
\end{abstract}

Keywords: blue stain fungus; coupled natural-human systems; Choristoneura freemani; Dendroctonus ponderosae; Dendroctonus rufipennis; Forest Health Protection; Ips confusus; US Forest Service; US Park Service

\section{Introduction}

Currently, environmental change is driving emerging forest-management challenges [1-3]. Faced with no-analogue conditions of drought, temperature, and non-native species invasions, managers from private and public entities alike report resource and knowledge limitations that make it increasingly difficult to achieve management objectives [4-6]. Moreover, global-change drivers operate at large spatial scales, resulting in landscape-scale conditions that exceed the land area of a given management unit. Conditions or events requiring management response, therefore, may require cross-boundary coordination among multiple managers. Examples include fuels management for wildfire prevention, active wildfire suppression, invasive species control, and forest pest outbreaks [7-11]. In multijurisdictional landscapes comprising multiple management units, termed management mosaics, the complexity of the social landscape thus further complicates responses to emerging ecological conditions [7]. 
In the US West, forested lands represent a valuable resource. Forests enhance carbon sequestration, prevent soil erosion and desertification, contribute to protecting watersheds and air quality, and provide habitats to a diverse array of species [12]. Forests are also expected to be significantly affected by shifts in temperature, precipitation, greenhouse gases, and insect pest outbreaks throughout the 21st century $[13,14]$. At low population levels, forest pests typically infest large, old, and weakened trees, and resulting tree mortality serves to recycle nutrients and create openings for regeneration [15]. However, pest populations periodically erupt into large-scale outbreaks capable of killing mature trees over thousands of acres. Recent forest pest outbreaks, linked to climate change, have led to unprecedented rates of mortality in high-elevation five-needle pines in North America, with over 46 million ha affected since the 1990s in western North America alone [16-18]. When these outbreaks cross jurisdictional boundaries, the mechanisms and effectiveness of management responses can vary in different parts of the outbreak, based on differences in the availability of resources, variable policies, and different management missions and mandates associated with different jurisdictions.

The goal of this study was to investigate the effect of management mosaic social complexity on the effectiveness of forest pest outbreak responses in two case study landscapes. We focused on the Protected Area-Centered Ecosystems (PACEs) sensu [19] containing Rocky Mountain National Park (ROMO) in Colorado and Grand Canyon National Park (GRCA) in Arizona, Utah, and New Mexico. A PACE is defined as the cohesive ecosystem surrounding and including a protected area, with its boundaries defined by ecotones rather than administrative jurisdictional borders sensu [19]. Both the ROMO and GRCA PACEs contain mosaics of federal and non-federal land ownerships. Within these PACEs, the species responsible for the greatest cumulative acreage of forest damage over the past twenty years include the western spruce budworm (Choristoneura freemani) and several species of bark beetle-including the piñon ips (Ips confuses), spruce beetle (Dendroctonus rufipennis), and mountain pine beetle (Dendroctonus ponderosae). Climate change is expected to increase the activity of several of these pest species within the PACE study regions and could result in increased tree mortality [14,16,20-22].

There are a number of tactics that managers may employ in response to a forest pest outbreak. These include spraying bifenthrin or carbaryl or applying pheromones to directly diminish the abundance of pest insects, as well as mechanical thinning, hand thinning, or prescribed burning to reduce the density of vulnerable trees and slow or halt the outbreak's spread [23]. In different jurisdictions, managers may elect different management methods, based on personal experience, preference and education level, availability of money and time, the existence of policies that restrict certain activities, and their management objectives $[7,9,24]$. In addition, management tactics selected by neighboring managers may influence a given jurisdiction, either because of social pressures or incentives or because neighboring conditions change in response to such tactics. The result is a complex social-ecological system, wherein administrative partitioning (the division of ecologically similar land parcels into different ownerships) may affect the outcome of forest pest outbreaks on management mosaic landscapes.

In the U.S., undeveloped public lands are divided among multiple federal management agencies, including the United States Forest Service (USFS), National Park Service (NPS), and Bureau of Land Management (BLM). Counties, states, tribes, city governments, and private landowners manage other lands. Administrative partitioning can split previously united land parcels, with these land parcels then falling under very different management regimes [25]. The NPS maintains a more single-use mission focused on protecting historic and natural heritage sites and the wildlife associated with these areas for the enjoyment of the public in perpetuity, whereas the USFS and BLM exhibit a multi-use mission that advocates both the conservation and the use of natural resources under their management [26]. State land also often falls under a multi-use mandate, as states manage land for both recreation and state profit. Counties, city governments, tribes, and private landowners may have either single-use or multi-use missions depending on their location and community needs. 
In order to explore how such management mosaics influence the effectiveness of outbreak response, we used semi-structured interviews [27,28], in combination with an electronic survey administered through Qualtrics [29], to understand the pest outbreak experience of diverse managers from the two case-study systems. Our study was exploratory in nature, limited to managers of forested lands within the two PACEs and thus limited in terms of both participant sample size and geographic scope. Nevertheless, participants provided insightful reflections on both the challenges they have experienced in cross-boundary pest outbreak response and potential remedies that might improve response effectiveness.

\section{Materials and Methods}

\subsection{Case Study Systems}

Both case study PACEs are located at high elevations (mean elevation $2400 \mathrm{~m}$ in the ROMO PACE and $1700 \mathrm{~m}$ in the GRCA PACE) in arid, western US states (Figure 1). Both PACEs contain a mix of land-cover types, including grasslands, oak and piñon-juniper woodlands, sagebrush steppe, and temperate evergreen forests. The GRCA PACE is relatively sparsely settled, with large areas of public and ranch lands as well as Native American reservation lands. The ROMO PACE is more densely populated and includes the Colorado Front Range-a region of rapid human population growth with a high density of ranchettes, small towns, and outdoor-recreation opportunities. The ROMO study area was heavily impacted in recent years by two native bark beetle species, the mountain pine beetle and the spruce beetle [30,31]. Prior to the mountain pine beetle epidemic, the average canopy tree density in ROMO was approximately 974 canopy $t \mathrm{ha}^{-1}$ [30]. Following the outbreak, this number was reduced to 494 canopy tha ${ }^{-1}$ [30]. Some of the highest levels of tree mortality occurred in forests within the PACE study area: the Arapaho and Roosevelt National Forest, Medicine Bow Routt National Forest, and White River National Forest [32] The spruce beetle also had a significant impact on the ROMO region landscape and remains active in Colorado [31].

In the GRCA study area, two native insects, the piñon ips and western spruce budworm, were found to have been active over the past two decades. From 2000-2003, a particularly severe drought resulted in unusually high levels of piñon pine (Pinus edulis) mortality throughout the southwestern U.S. [33,34]. In 2002, Arizona and New Mexico had one of the driest and warmest years on record [34]. By 2003, 768,902 ha of piñon woodland in these two states alone showed evidence of bark-beetle activity [35]. Regional piñon mortality rose by at least $200 \%$ during this drought, and certain areas had greater than 90\% mortality. Throughout these intensive mortality events, the piñon ips bark beetle remained the most lethal insect to piñon trees [16]. The western spruce budworm has also impacted the forests of the Southwest [36]. The western spruce budworm is a destructive defoliator that can cause tree growth loss, top-kill, and, after successive years of defoliation, potential mortality $[36,37]$. Within our GRCA PACE study region, the western spruce budworm damaged 61736 ha and remains a challenge for natural resource managers [35].

Forest records show that between 1997-2017, mountain pine beetle and spruce beetle impacted a cumulative 1.5 million ha of forest area in the 8.5 million ha ROMO PACE [38]. In the GRCA PACE, piñon ips and western spruce budworm damaged 144,079 ha of the 1.1 million ha (about $14 \%$ of the PACE region) that is covered by forest vegetation [38].

\subsection{Interview Methodology}

To explore how administrative partitioning influences the regional effectiveness of forest pest management, we conducted semi-structured interviews and electronic surveys with agency personnel. We used a criteria-sampling technique to identify and send interview requests to a subgroup of the population of land managers within each PACE region $[27,28]$. Criteria included that the respondent (1) had been with their organization for at least one year, (2) had been or was actively involved with forest pest management, and (3) currently worked or had worked within one of the PACE study areas. We identified additional interviewees through snowball sampling [39]. 

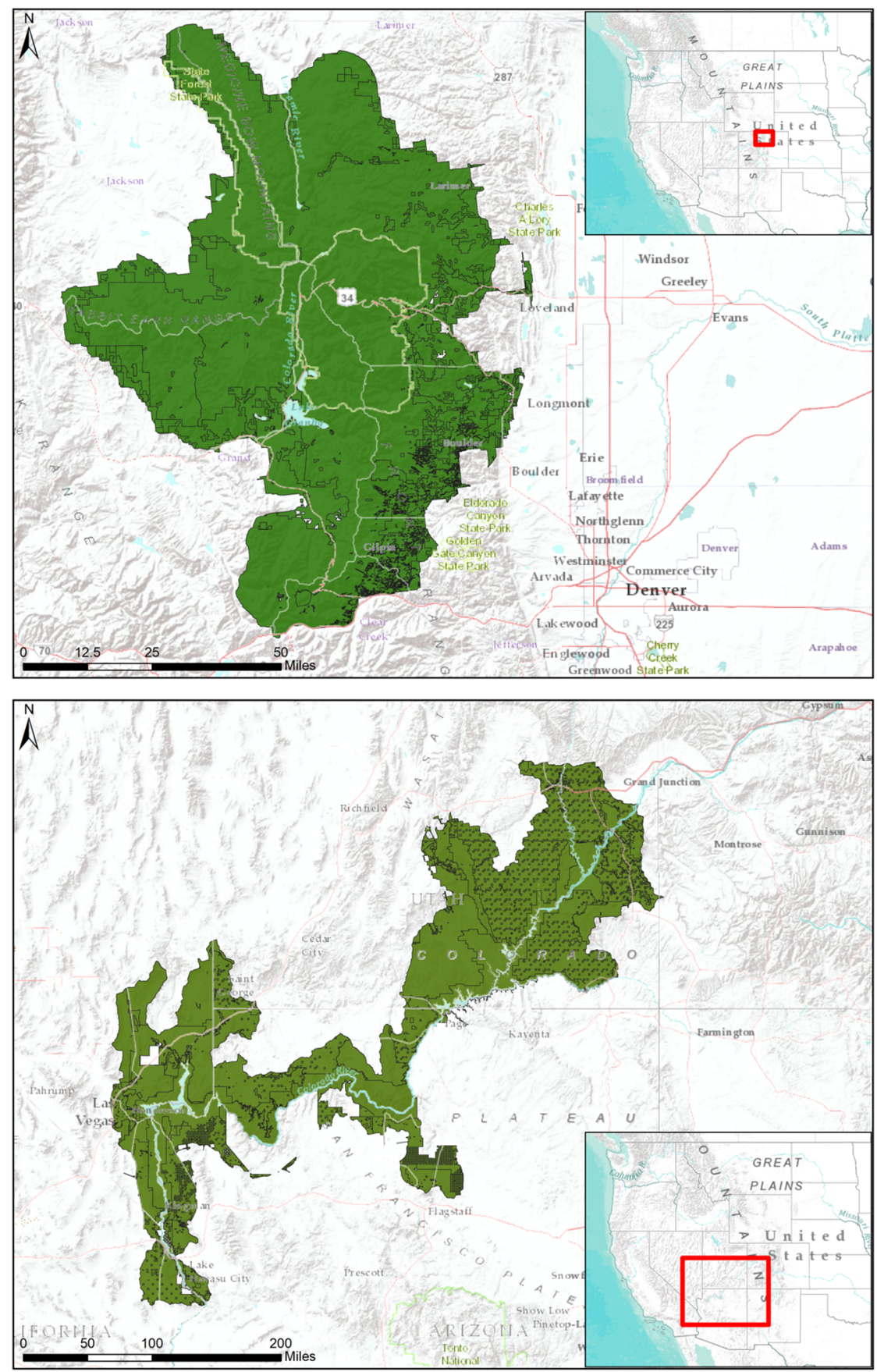

Figure 1. Locations of the Rocky Mountain National Park (ROMO) and Grand Canyon National Park (GRCA) Protected Area-Centered Ecosystem (PACE) study sites. Each PACE includes the ecosystem surrounding and including a protected area, with PACE boundaries defined by ecotones rather than administrative jurisdictions.

We conducted interviews both in person and over the phone between June and September of 2018. With permission, we recorded all interviews, which ranged 30-90 min. The interview questionnaire included a series of 12 questions used for analysis in this study (Table S1). Interview questions focused on identifying how bordering agencies managed pest outbreaks differently, how agencies responded when an outbreak crossed jurisdictional boundaries, and whether individuals found that increasing administrative partitioning increased barriers to pest management. We transcribed interviews using NCH Software's Express Scribe Transcription Pro after collecting interview recordings. Following transcription, we used a general inductive approach to conduct data analysis [40] 
along with the inductive coding procedure [41]. We completed the analysis using QSR International's NVivo 10 [42] qualitative data analysis software. All interview transcripts were processed with a first and second cycle of coding [43]. Following coding, we used a streamline codes-to-theory model for qualitative inquiry [40]. Upon final reporting, individuals' identities were kept anonymous.

\subsection{Survey Methodology}

An electronic survey was administered during the interviews and a link to the survey was emailed to other individuals in the study area who met our criteria. We surveyed all individuals who met the criteria rather than a random sample due to the relatively small size of our target population [44-46]. We also requested demographic information from our survey participants (agency mandate, time with agency, age, education level, PACE region affiliation, and discipline) in order to investigate the potential variables related to different experiences with cross-boundary pest outbreak management [41].

The survey included three sections: (a) a series of 7-point Likert scale questions [41]; (b) open-ended qualitative questions regarding interagency management sentiments, most frequently experienced barriers to management, management techniques; and (c) the demographics section. The survey included novel questions such as, "Do pest outbreaks that cross jurisdictional boundaries pose unique challenges to pest management?", as well as questions that were adapted from the literature and examined barriers to interagency collaboration $[17,25]$. We analyzed Likert-scale questions using nonparametric statistics [47]. In order to compare responses among subgroups of respondents, we classified respondents by their response to the following demographic questions: agency mandate (single-use or multiple-use), time with agency ( $<10$ years or $>10$ years), age group ( $26-45$ or $46-65)$, education level (advanced degree or <advanced degree), PACE region (ROMO or GRCA), and self-reported discipline (respondents could select from Forestry, Ecology, Entomology, Wildlife Biology, or Other, for which categories were selected to represent the various educational backgrounds common in forest pest management positions). Due to our small sample size and because the data failed to meet the assumption of normal distribution for linear models, we used Mann-Whitney U tests to identify differences by agency mandate, time with agency, age group, education level, and PACE region [47]. We employed KruskalWallis tests to identify differences among the discipline groups and Mann-Whitney $U$ tests for post hoc analysis of pairwise differences between disciplines [47]. Because the sample size of participants was necessarily limited, significance was accepted at $p \leq 0.1[45,48]$. Quantitative analyses were performed in R (RStudio Team 2016). We analyzed the responses to open-ended questions through systematic theming and categorization [41,49].

Because this study collected information on professional experiences but no personal information that could be damaging to participants, and because participants were guaranteed anonymity, this study was granted exemption from a full ethics review by the Northern Arizona University Institutional Review Board.

\section{Results}

\subsection{Semi-Structured Interviews}

Nine individuals from the Grand Canyon National Park protected area-centered ecosystem (GRCA PACE) and eleven individuals from the Rocky Mountain National Park protected area-centered ecosystem (ROMO PACE) participated in in-person or phone interviews from June to September 2018. Respondents ranged in terms of time with agency from one year to several decades. Respondents also varied across age groups and education. Respondents from ROMO represented the USFS, NPS, Colorado State Forest Service, County, and City governments. Respondents from GRCA represented the USFS and NPS, which manage more than $90 \%$ of the forested land in the GRCA PACE.

We examined the definition of "effective" pest management through individual definition and by asking interviewees to explain the management efforts they had used (Table 1). Some respondents quantified effectiveness as keeping target trees alive or keeping a certain 
percentage of the stand alive. Respondents also highlighted secondary indicators of forest pest management effectiveness, such as impacts to water quality or visitor experience. Nine respondents stated that they commonly assessed effectiveness through on-the-ground monitoring, but funding and time constraints were acknowledged as limitations to monitoring opportunities. The types of forest pest management employed varied amongst respondents, and included treatments such as spraying bifenthrin or carbaryl, applying pheromones, mastication, mechanical thinning, hand thinning, or prescribed burning.

Table 1. Components of effective pest response as identified by interviewees, with example quotes illustrating each definition of effectiveness. "References" refers to the number of unique mentions of each definition.

\begin{tabular}{|c|c|c|}
\hline Category & References & Example Statements \\
\hline Tree mortality & 4 & $\begin{array}{c}\text { "In terms of effectiveness for forest pests, if we had } \\
\text { target trees that we wanted to keep alive that's our } \\
\text { metric for success." }\end{array}$ \\
\hline Secondary/indirect impacts & 2 & $\begin{array}{l}\text { "Second thing [in determining effectiveness] [it is } \\
\text { important to identify] some of the indirect } \\
\text { consequences of this outbreak and [whether they] } \\
\text { were significant or not, be it water quality or } \\
\text { indirect impacts to visitors." }\end{array}$ \\
\hline Met management objectives & 4 & $\begin{array}{l}\text { "I view effectiveness based on what was the } \\
\text { objective? Was our objective to go in and suppress } \\
\text { current activity or is the objective to go in and thin } \\
\text { the stand for resiliency? It's all based on objectives } \\
\text { in my opinion and setting up those expectations } \\
\text { and if we met the expectations ... you know, did } \\
\text { we come close to our objective or did we not?" }\end{array}$ \\
\hline Improved forest health & 3 & $\begin{array}{c}\text { "I think effectiveness is changing the stand } \\
\text { conditions, promote diversity, open up a forest, } \\
\text { make it healthier." }\end{array}$ \\
\hline Planning leading to action & 1 & $\begin{array}{l}\text { "Field trips, conference calls, etc., did they actually } \\
\text { lead to something getting done on the ground? If } \\
\text { you're not getting around to doing something on } \\
\text { the ground, that's an issue." }\end{array}$ \\
\hline
\end{tabular}

Interviewees were asked about how the presence of administrative boundaries affects the management of pest outbreaks. Respondents highlighted that distinct agency missions and policies can affect stand conditions and potential outbreak risk, as illustrated by the following sample quotes:

"The NPS has a very different mission than the USFS. On their side of the fence it's going to be denser and potentially more at risk of bark beetle outbreaks compared to adjacent land that might have been thinned." [P3]

"We [USFS] are directed to manage for resilience, for disturbance, especially fire, insects, and disease. The Park Service, the Interior, would probably have a different philosophy about that. We can only do so much on our land and then you know what happens on the other side is more of nature's course. It's a different philosophy for sure." [P3]

"In some cases you will see agencies that have less federal bureaucracy than us [USFS] and a different mandate ... taking basal area in ponderosa pine down to 60 BA whereas the Forest Service might be doing 100 or 110 . They can be a little bit more aggressive, again they just don't have as many constraints which is great. In terms of forest health it's kind of a better scenario." [P1] 
Respondents commented that the increasing complexity of management mosaics (i.e., a larger number of land management jurisdictions) led to greater challenges with outbreak response (Table 2). Four of our interviewees (20\%) mentioned that increased complexity led to bringing more players to the table; this in turn increases the costs of collaboration by expanding the number of individual interactions and the time investment required to establish effective coordination [50]. Three respondents (15\%) noted that it can be challenging to identify a common purpose and drive when multiple groups are acting collaboratively. Respondents also noted that specific federal policies can impede the effective management of forest pest outbreaks. Specifically, a Forest Health Protection interviewee referenced a policy directly related to prevention vs. suppression funding:

"What we can do on USDA lands is we can provide funding for prevention work. Prevention is better, this is the ideal. We can only provide funding for suppression on any non-USDA land." [P14]

Table 2. Challenges associated with cross-boundary forest pest outbreaks identified across interview respondents, with example quotes illustrating each challenge. "References" refers to the number of unique mentions of each challenge.

\begin{tabular}{|c|c|c|}
\hline Category & References & Example Statements \\
\hline Differing agency missions/objectives & 18 & $\begin{array}{c}\text { "Our [NPS vs. USFS] missions are separate and our } \\
\text { philosophies are separate." }\end{array}$ \\
\hline Bureaucracy & 7 & $\begin{array}{l}\text { "When we [USFS] work with folks like the Bureau of Indian } \\
\text { Affairs and the tribes, they have a lot more flexibility and dual } \\
\text { management across their lands. They still have the National } \\
\text { Environmental Policy Act and environmental restrictions, but } \\
\text { not as many. It doesn't limit them as much." }\end{array}$ \\
\hline $\begin{array}{l}\text { Complex management mosaics with } \\
\text { many stakeholders }\end{array}$ & 6 & $\begin{array}{c}\text { "When you have to plan and implement with a large } \\
\text { collaborative and lots of partners, that takes a lot of effort. It is } \\
\text { much more difficult than if you are a manager that is just in } \\
\text { charge of one land base." }\end{array}$ \\
\hline $\begin{array}{l}\text { Little to no collaboration in long-term land } \\
\text { management planning }\end{array}$ & 5 & $\begin{array}{l}\text { "Colorado and the BLM and the State ... we [USFS] haven't sat } \\
\text { down with them and really talked about long-term plans." }\end{array}$ \\
\hline Tragedy of the commons & 5 & $\begin{array}{l}\text { "We [USFS] spend millions of dollars on treatment, so if we } \\
\text { have a neighbor that's not keeping up it's very difficult." }\end{array}$ \\
\hline Funding projects across boundaries & 4 & $\begin{array}{l}\text { "What we can do on USDA lands is we can provide funding for } \\
\text { prevention work. Prevention is better, this is the ideal. On tribal } \\
\text { lands we can only provide funding for suppression. We can } \\
\text { only provide funding for suppression on any non-USDA land." }\end{array}$ \\
\hline Federal policies & 4 & $\begin{array}{l}\text { "In consistency with federal policies, there was no management } \\
\text { going down in the wilderness areas." }\end{array}$ \\
\hline Government employee turnover & 4 & $\begin{array}{c}\text { "So I've only been with the government for three years now, but } \\
\text { I see now a main problem is that it is a constantly revolving } \\
\text { door. There's constantly new employees." }\end{array}$ \\
\hline Lack of consistent messaging & 1 & $\begin{array}{l}\text { "We probably could have done a better job of campaigning to } \\
\text { the general public about blue stain when the epidemic started } \\
\text { just to get that thought process out of people's minds. It's } \\
\text { [lumber] just one grade lower than it probably could be graded } \\
\text { and then they [agencies selling lumber] don't get as much } \\
\text { money for it." }\end{array}$ \\
\hline
\end{tabular}

Effectively, this policy restricts preventative silviculture treatments such as species manipulation and age-class manipulation on non-USDA land using funds from Forest Health Protection - a branch of the US Forest Service concerned with maintaining forest health, and a key source of federal funding. Respondents also highlighted cross-boundary outbreak management challenges such as lack of consistent messaging across agencies, the 
frustration of working in or with a bureaucracy, and little to no collaboration in long-term management plans (Table 2).

Though outbreaks that cross jurisdictional boundaries can pose challenges for land managers, interviewees also brainstormed solutions. Two respondents from ROMO mentioned it would have been helpful to enhance education about the blue stain fungus that maintains a symbiotic relationship with the mountain pine beetle:

"[At] places like Home Depot and Lowe's ... what happens with the blue stain is it drops lumber another grade on the grading scale and so it puts it at a lower grade stud. It doesn't actually affect the wood, it's just a perception thing. Oh, someone looks at that and they go oh ... it's got a blue color to it, it's probably got rot in it. I don't want to buy that. So, we probably could have done a better job of campaigning to the general public about blue stain when the epidemic started to get that thought process out of people's minds." [P5]

One respondent mentioned the need for enhanced education surrounding blue stain fungus and a need for consistent messaging. They recommended that federal, state, and local governments deliver the same message regarding the structural integrity of bluestained timber. Without coherent messaging, salvage logging became less productive for agencies that required profitable timber sales to effectively remove beetle-infested trees from the landscape.

Additional interviewees noted other solutions for managing cross-boundary outbreaks, including improved education surrounding the funding capabilities of Forest Health Protection, increasing the number of timber mills, promoting the presence of university research on and around federal lands, and instituting additional collaborative policies such as Good Neighbor Authority, a policy that allows the US Forest Service to make agreements to manage forests with state forestry agencies.

\subsection{Survey Results}

A total of 34 respondents completed the survey. Fifty-three percent of respondents were from the ROMO PACE and $47 \%$ of respondents were from the GRCA PACE. Although the two PACEs differ in land area, obtaining a similar number of responses from each PACE facilitated both qualitative and quantitative (statistical) comparisons between the two PACEs. In summarizing the full set of responses to questions, it is important to recognize that perspectives from the two PACEs are represented approximately equally. Survey respondents were split across agencies with single-use $(29 \%)$ and multi-use $(71 \%)$ missions. Thirty-two percent of respondents had spent less than ten years with their agency and $68 \%$ had spent more than 10 years with their respective agency. The participants' discipline backgrounds included forestry (66\%), entomology (14\%) and ecology $(20 \%)$.

On a 7-point Likert scale $(1=$ strongly disagree, $7=$ strongly agree $)$ respondents agreed that pest outbreaks which cross jurisdictional boundaries pose unique challenges to pest management $(\bar{x}=6.4, s=0.7)$ (Tables S2-S7). Respondents also highlighted a variety of barriers to interagency collaboration. Respondents were most likely to agree that the "bureaucratic nature of federal land management agencies" was the most frequently experienced barrier to interagency collaboration both throughout their career and in the last year. "Difficulties associated with sharing budgets on joint work projects", "disparities in agency culture", and "distinct mandates for governmental agencies" were also cited as frequently experienced barriers to interagency collaboration (Table 3).

We examined the effect of agency mission, PACE region, time with agency, age group, discipline, and education level on respondents' answers to Likert scale and scalar questions. The mean Likert scale degree of agreement by respondents from single-use vs. multiple-use agencies to, "I see interagency collaboration as being a key tool in the present/future as we continue to deal with landscape-level issues such as pest outbreaks" were 6.4 and 6.8 respectively; distributions in the two groups differed significantly $(\mathrm{w}=77, \mathrm{n} 1=\mathrm{n} 2=34$, $p<0.1$ two-tailed) (Table S2). Multiple-use and single-use agencies also exhibited different levels of agreement with, "I find it easy to work with personnel from neighbor- 
ing agencies" with mean scores of 5.6 and 4.9 and significantly different distributions ( $\mathrm{w}=170, \mathrm{n} 1=\mathrm{n} 2=34, p<0.1$ two tailed) (Table S2). There was no significant difference between respondents from the two different PACEs (Table S3).

Table 3. Survey respondents identified barriers to interagency collaboration, distinguishing between those experienced in the past year and those experienced most frequently over the course of their careers.

\begin{tabular}{|c|c|c|}
\hline Barriers & $\begin{array}{l}\text { Experienced Frequently throughout } \\
\text { Career (\% of Respondents) }\end{array}$ & $\begin{array}{l}\text { Experienced in the Past Year } \\
\text { (\% of Respondents) }\end{array}$ \\
\hline Distinct mandates for governmental agencies & 10.2 & 12.3 \\
\hline $\begin{array}{l}\text { Bureaucratic nature of federal land } \\
\text { management agencies }\end{array}$ & 27.3 & 26.3 \\
\hline Trust issues/turf disputes & 5.7 & 3.5 \\
\hline $\begin{array}{l}\text { Prioritizing internal goals as opposed to } \\
\text { collective goals }\end{array}$ & 12.5 & 10.5 \\
\hline Disparities in agency culture & 17.1 & 7.0 \\
\hline $\begin{array}{l}\text { Difficulties associated with sharing budgets on joint } \\
\text { work projects }\end{array}$ & 19.3 & 15.8 \\
\hline I have not participated in interagency collaboration & 4.6 & 8.8 \\
\hline $\begin{array}{l}\text { I have participated in interagency collaboration, but } \\
\text { experienced no difficulties }\end{array}$ & 1.1 & 10.5 \\
\hline \multicolumn{3}{|l|}{ Other. Please describe: } \\
\hline $\begin{array}{l}\text { Taking the time to understand everyone's goals } \\
\text { and objectives }\end{array}$ & 1.1 & 3.5 \\
\hline Communication & 1.1 & 1.8 \\
\hline
\end{tabular}

\section{Discussion}

Overall, our findings align with our hypothesis that increased administrative partitioning in a management mosaic negatively influences the regional effectiveness of forest pest management. Individual agencies have differing missions, mandates, capacities, and resources that can make it difficult to mount a cohesive response.

In addition, our research highlighted unique challenges caused by cross-boundary outbreaks. Policy and regulatory decisions can result in unequal pest response across a landscape: for example, as our interviewees pointed out, little to no active pest management occurs in wilderness areas, where natural processes are intended to proceed without interference. However, in the face of pests that can threaten forest structure and composition, a lack of pest management could result in declining biodiversity within such areas or across the landscape. By contrast, active pest responses outside of wilderness areas requires resources, information, and funding, and runs the risk that disturbances associated with pest response will itself impact biodiversity. Furthermore, if effective pest-response efforts are employed in only some administrative units, other units could act as pest reservoirs from which infestations are able to continuously spread into neighboring units, overriding those ongoing efforts [7]. In light of these complex spatial dynamics, it may be necessary in some cases to ensure that forest biodiversity is protected by retaining certain pest-free "reserves" alongside wilderness areas-a challenge requiring decision making at a landscape scale.

Specific agency mandates may also create a sort of "gradient" of thinning that can affect pre-outbreak conditions. This sort of thinning differential can also be caused by the implementation of specific policies. The Healthy Forest Reforestation Act (HFRA) of 2003 shaped the way the USFS and BLM are able to manage their lands, particularly in relation to forest pests [51]. As noted by Six et al. [51], the HFRA lessened the public's ability to challenge certain timber projects in court and reduced the level of environmental analysis required for certain timber projects under the National Environmental Policy 
Act. HFRA authorizes this streamlined process for timber projects on BLM and USFS land where the existence of an epidemic of disease or insects, or the presence of such an epidemic on immediately adjacent land, poses a risk. As more preservation-oriented agencies such as the NPS are generally not licensed to employ such policies and conduct thinning at large scales, these sorts of policy differences between federal agencies can result in cross-boundary management challenges, whereby timber projects may be employed on one side of a boundary to manage an outbreak but other methods are employed on the other side of the boundary. Even where timber is allowed, however, market factors play an important role in determining whether or not they can be effectively employed. The removal of vulnerable trees in some contexts is hindered by a lack of timber harvesting infrastructure, cost versus benefit realities, and a lack of national public support for timber management programs [52].

Another challenge expressed by our respondents was creating a collaborative with no formal agreement outlining policies for conflict resolution between agencies. Our findings are consistent with other collaborative research, which outlines that a formal agreement can help parties explicitly define their expectations regarding their transactions and each side's role [53]. Coordination-oriented provisions in an agreement are also important, as they can mitigate the problems that misunderstandings can cause in collaboration among wellintentioned parties [53]. As noted by Malhotra and Lumineau [53], formal coordination structures may be vital for collaboration following a conflict, because disputing parties are not likely to engage in the kinds of spontaneous communication that mitigate conflict and promote positive solutions. The formalization of agreements may be particularly important when there are a large number of players that need to come to the table in order to coordinate an effective response to an outbreak: the sheer number of relationships that must be developed and cultivated can increase the transaction cost of the coordination effort [50,54] by requiring an increased investment of time and resources, and such investments may deter participation if roles and expectations are not clearly delineated.

Our interviews also suggested that numerous viable solutions exist to tackle crossboundary management challenges. For one, respondents mentioned that consistent messaging surrounding pest outbreaks can be key to getting private landowners involved in management, and could help improve education surrounding the structural integrity of lumber with blue stain fungus. In McGinley et al. [55], the authors reaffirm the importance of disseminating consistent messages to the public. Their results highlight that inconsistent messages from agencies can cause the agency to lose credibility, and too many messages may diminish the effectiveness of communication with the public [55]. Finally, to increase FHP's efficacy and utility for land managers, a policy change may also be needed in how prevention vs. suppression funds are allocated. As FHP is only authorized to provide financial backing for prevention work on USDA lands, all non-USDA lands are limited to solely receiving funds for suppression. It would be more effective for regional forest management if FHP was authorized to fund prevention treatments across all jurisdictions.

The key findings from our survey include a significant difference in the mean level of agreement between agencies with single-use vs. multi-use missions to the statement, "I see interagency collaboration as being a key tool in the present/future as we continue to deal with landscape-level issues such as pest outbreaks". Overall, single-use agencies had a higher mean score-with single-use agencies including the NPS, a NGO, and a City government reporting their own unique single-use mission of managing their lands for recreation. A higher mean score could suggest that these single-use agencies view themselves as islands in need of collaboration in order to manage natural resources effectively on an ecosystem scale. In addition, we found a significant difference in mean scores between single-use and multiple-use agencies in the level of agreement with the statement, "I find it easy to work with personnel from neighboring agencies". In this case, single-use agencies had a lower mean score, implying that they may find it difficult to work with their neighboring agencies that operate under multi-use or even other single-use missions. This finding is supported by Fleming et al. [26], who showed that personnel of multiple-use agencies 
perceived lower mission misalignment with other federal land agencies with multiple-use land management missions than with federal land agencies with single-use missions. This perceived mission misalignment is likely to determine whether or not agency personnel are able to work with a neighbor with ease-which could have direct impacts on managing outbreaks that cross boundaries.

Our study identified specific barriers to cross-boundary management, which may assist managers in both better tailoring future forest management and streamlining potential interagency collaboration efforts. As climate change is expected to increase the activity of some forest pest species, including the mountain pine beetle, spruce beetle, western spruce budworm, and piñon ips [14,16,20-22], it is likely that agencies may experience these barriers at even greater scales. In order to initiate proactive future forest management, our study also highlights specific solutions to utilize when responding to outbreaks that cross boundaries. These findings suggest that further research should be conducted on the solutions highlighted here in order to assess their efficacy in managing cross-boundary outbreaks. Monitoring of relatively novel management policies such as the Good Neighbor Authority [51] and Forest Service Stewardship Agreements should be conducted at a socioecological level in an effort to understand both its implication for forest health and its effectiveness as perceived by bordering land managers. Efforts should also be made to understand the most valuable methods to improve awareness of cross-boundary federal technical and financial assistance resources related to forest health.

\section{Conclusions}

Forest pest outbreaks often cross federal, state, and local jurisdictions, creating conditions under which we can explore agency relationships and management strategies. Although this was a case study and thereby limited in both sample size and geographic extent, this research investigated how these jurisdictional boundaries impact pest management, the challenges that arise when cross-boundary outbreaks occur, and potential solutions to these challenges that may assist land managers in future forest stewardship. Through exploratory qualitative analysis, our research has highlighted a flexible toolbox of strategies that managers can employ in diverse ecosystems and regions. For example, participants identified a need for more scientific research that advances integrated forest pest management. Resource managers require up-to-date and scientifically-informed management approaches in order to address complex long-term challenges such as forest pest management, particularly in light of continued drought and similar changes that may limit the effectiveness of traditional management practices. When scientists plan research in collaboration with managers, this results in the co-production of actionable science [56] and can help managers best allocate resources based on scientific findings. Greater awareness of, and policy shifts regarding the USFS's Forest Health Protection branch are also needed. FHP represents one of the key forest health resources from the federal government, yet our survey indicated that a combined $18.5 \%$ of respondents either were not sure if their agency had "used funds and/or other resources from Forest Health Protection when dealing with pest management" or were entirely unfamiliar with FHP. Increased education surrounding FHP and the technical and financial assistance it provides is a key tool in improving future forest stewardship in the US. Based on our research we also recommend that policymakers reevaluate the USDA policy that limits FHP using prevention funds on non-USDA land; in general, flexibility in funding and other resources are likely necessary as forest managers across diverse systems confront emerging pest problems. Finally, this study suggests that organizing cross-boundary forest pest task force teams before forest pest population levels erupt could be beneficial. That is, managers working within management mosaics would benefit from the creation of collaboratives before an outbreak occurs, so that such task forces can mount quick responses. In the US, agencies interested in forming such task forces can utilize resources such as the 2013-2027 USFS National Insect and Disease Risk Map [57], which highlights where and when outbreaks of varying species are likely to 
occur. Predictive resources such as this could bring resources and personnel to the table before an epidemic spreads across a landscape.

This study explores the importance of social and ecological connections across jurisdictional boundary lines, with reference to forest pest outbreaks. Since outbreaks are expected to increase with a changing climate, it is vital for both forest health and overall community socioeconomic well-being to manage them as effectively as possible. The management challenges and potential solutions identified here may provide guidance and insights to agency personnel grappling with such disturbances across diverse forested regions.

Supplementary Materials: The following supporting information can be downloaded at: https: / / www.mdpi.com/article/10.3390/f13030395/s1, Table S1 presents the interview questions used in this study. Tables S2-S7 present means and variances of survey responses by respondent subgroups.

Author Contributions: Conceptualization, B.T., T.C., R.W.H. and C.A.; Methodology, B.T., T.C., R.W.H. and C.A.; Formal Analysis, B.T.; Investigation, B.T.; Resources, C.A.; Data Curation, B.T. and C.A.; Writing-Original Draft Preparation, B.T.; Writing-Review \& Editing, T.C., R.W.H. and C.A.; Supervision, C.A.; Funding Acquisition, C.A. All authors have read and agreed to the published version of the manuscript.

Funding: Funding for this study was provided by the National Science Foundation (NSF award number: 1617309).

Institutional Review Board Statement: The study was conducted in accordance with the Declaration of Helsinki, and approved by the Institutional Review Board of Northern Arizona University (protocol code 1248221-1, 29 May 2018).

Informed Consent Statement: Informed consent was obtained from all subjects involved in the study.

Data Availability Statement: Upon manuscript acceptance, data used in these analyses will be deposited in the Dryad Digital Repository.

Acknowledgments: The authors thank all agency staff from the GRCA and ROMO PACEs who took part in surveys and interviews.

Conflicts of Interest: The authors declare no conflict of interest.

\section{References}

1. Bugmann, H.; Palahi, M.; Bontemps, J.D.; Tome, M. Trends in modelling to address forest management and environment challenges in Europe. For. Syst. 2010, 19, 3-7.

2. Bouriaud, L.; Marzano, M.; Lexer, M.; Nichiforel, L.; Reyer, C.; Temperli, C.; Peltola, H.; Elkin, C.; Duduman, G.; Taylor, P.; et al. Institutional factors and opportunities for adapting European forest management to climate change. Reg. Environ. Chang. 2015, 15, 1595-1609. [CrossRef]

3. Fady, B.; Cottrell, J.; Ackzell, L.; Alía, R.; Muys, B.; Prada, A.; González-Martínez, S.C. Forests and global change: What can genetics contribute to the major forest management and policy challenges of the twenty-first century? Reg. Environ. Chang. 2016, 16, 927-939. [CrossRef]

4. Hobbs, R.J.; Hallett, L.M.; Ehrlich, P.R.; Mooney, H.A. Intervention ecology: Applying ecological science in the twenty-first century. BioScience 2011, 61, 442-450. [CrossRef]

5. Park, A.; Puettmann, K.; Wilson, E.; Messier, C.; Kames, S.; Dhar, A. Can boreal and temperate forest management be adapted to the uncertainties of 21st century climate change? Crit. Rev. Plant Sci. 2014, 33, 251-285. [CrossRef]

6. Lawrence, A. Adapting through practice: Silviculture, innovation and forest governance for the age of extreme uncertainty. For. Policy Econ. 2017, 79, 50-60. [CrossRef]

7. Epanchin-Niell, R.S.; Hufford, M.B.; Aslan, C.E.; Sexton, J.P.; Port, J.D.; Waring, T.M. Controlling invasive species in complex social landscapes. Front. Ecol. Environ. 2010, 8, 210-216. [CrossRef]

8. Fischer, A.P.; Charnley, S. Risk and cooperation: Managing hazardous fuel in mixed ownership landscapes. Environ. Manag. 2012, 49, 1192-1207. [CrossRef]

9. Epanchin-Niell, R.S.; Wilen, J.E. Individual and cooperative management of invasive species in human-mediated landscapes. Am. J. Agric. Econ. 2015, 97, 180-198. [CrossRef]

10. Fischer, A.P.; Klooster, A.; Cirhigiri, L. Cross-boundary cooperation for landscape management: Collective action and social exchange among individual private forest landowners. Landsc. Urban Plan. 2019, 188, 151-162. [CrossRef] 
11. Charnley, S.; Kelly, E.C.; Fischer, A.P. Fostering collective action to reduce wildfire risk across property boundaries in the American West. Environ. Res. Lett. 2019, 15, 025007. [CrossRef]

12. Corley, J.C.; Jervis, M.A. Forest pest management: A global challenge. Int. J. Pest Manag. 2012, 58, 193-194. [CrossRef]

13. McNulty, S.G.; Aber, J.D. US national climate change assessment on forest ecosystems: An introduction. BioScience 2001, 51, 720. [CrossRef]

14. Bentz, B.J.; Régnière, J.; Fettig, C.J.; Hansen, E.M.; Hayes, J.L.; Hicke, J.A.; Kelsey, R.G.; Negrón, J.F.; Seybold, S.J. Climate change and bark beetles of the western United States and Canada: Direct and indirect effects. BioScience 2010, 60, 602-613. [CrossRef]

15. Jenkins, M.J.; Hebertson, E.; Page, W.; Jorgensen, C.A. Bark beetles, fuels, fires and implications for forest management in the Intermountain West. For. Ecol. Manag. 2008, 254, 16-34. [CrossRef]

16. Raffa, K.F.; Aukema, B.H.; Bentz, B.J.; Carroll, A.L.; Hicke, J.A.; Turner, M.G.; Romme, W.H. Cross-scale drivers of natural disturbances prone to anthropogenic amplification: The dynamics of bark beetle eruptions. Bioscience 2008, 58, 501-517. [CrossRef]

17. Petersen, B.; Wellstead, A.M. Responding to forest catastrophe in the face of unprecedented forest challenges: The emergence of new governance arrangements. ISRN Econ. 2014, 20, 1-10. [CrossRef]

18. Gibson, K.; Skov, K.; Kegley, S.; Jorgensen, C.; Smith, S.; Witcosky, J. Mountain pine beetle impacts in high-elevation five-needle pines: Current trends and challenges. In Northern Region, Forest Health Protection; USDA Forest Service: Washington, DC, USA, 2018.

19. Hansen, A.J.; Davis, C.R.; Piekielek, N.; Gross, J.; Theobald, D.M.; Goetz, S.; Melton, F.; DeFries, R. Delineating the ecosystems containing protected areas for monitoring and management. BioScience 2011, 61, 363-373. [CrossRef]

20. Hansen, A.J.; Neilson, R.P.; Dale, V.H.; Flather, C.H.; Iverson, L.R.; Currie, D.J.; Shafer, S.; Cook, R.; Bartlein, P.J. Global Change in Forests: Responses of Species, Communities, and BiomesInteractions between Climate Change and Land Use Are Projected to Cause Large Shifts in Biodiversity. BioScience 2001, 51, 765-779. [CrossRef]

21. Rousseau, J.; Bauce, É.; Lavallée, R.; Guertin, C. Winter mortality and supercooling point of the spruce beetle (Coleoptera: Curculionidae) not affected by host tree vigor in Nova Scotia, Canada. J. Acad. Entomol. Soc. 2012, 8, 1-10.

22. Macfarlane, W.W.; Logan, J.A.; Kern, W.R. An innovative aerial assessment of Greater Yellowstone Ecosystem mountain pine beetle-caused whitebark pine mortality. Ecol. Appl. 2013, 23, 421-437. [CrossRef] [PubMed]

23. Coggins, S.B.; Coops, N.C.; Wulder, M.A.; Bater, C.W.; Ortlepp, S.M. Comparing the impacts of mitigation and non-mitigation on mountain pine beetle populations. J. Environ. Manag. 2011, 92, 112-120. [CrossRef] [PubMed]

24. Aslan, C.E.; Souther, S.; Stortz, S.; Sample, M.; Sandor, M.; Levine, C.; Samberg, L.; Gray, M.; Dickson, B. Land management objectives and activities in the face of projected fire regime change in the Sonoran desert. J. Environ. Manag. 2021, $280,111644$. [CrossRef] [PubMed]

25. Holcomb, C.M.; Sisk, T.D.; Dickson, B.D.; Sesnie, S.E.; Aumack, E.N. Administrative boundaries and ecological divergence: The divided history and coordinated future of land management on the Kaibab Plateau, Arizona, USA. In Research, Environmental Planning, and Management for Collaborative Conservation; University of Arizona Press: Tucson, Arizona, USA, 2011; pp. 1-20.

26. Fleming, C.J.; McCartha, E.B.; Steelman, T.A. Conflict and collaboration in wildfire management: The role of mission alignment. Public Adm. Rev. 2015, 75, 445-454. [CrossRef]

27. Patton, M.Q. Qualitative Research and Evaluation Methods; Sage Publications, Inc.: Thousand Oaks, CA, USA, 2002.

28. Palinkas, L.A.; Horwitz, S.M.; Green, C.A.; Wisdom, J.P.; Duan, N.; Hoagwood, K. Purposeful sampling for qualitative data collection and analysis in mixed method implementation research. Adm. Policy Ment. Health Ment. Health Serv. Res. 2015, 42, 533-544. [CrossRef]

29. Ausderau, K.K.; Furlong, M.; Sideris, J.; Bulluck, J.; Little, L.M.; Watson, L.R.; Baranek, G.T. Sensory subtypes in children with autism spectrum disorder: Latent profile transition analysis using a national survey of sensory features. J. Child Psychol. Psychiatry 2014, 55, 935-944. [CrossRef]

30. Diskin, M.; Rocca, M.E.; Nelson, K.N.; Aoki, C.F.; Romme, W. Forest developmental trajectories in mountain pine beetle disturbed forests of Rocky Mountain National Park, Colorado. Can. J. For. Res. 2011, 41, 782-792. [CrossRef]

31. Barry, P.; Duda, J.; Garrison, K.; Lockwood, R.; Mason, L.; Matthews, S.; Mueller, K.; Reader, T.; West, D. 2017 Report on the Health of Colorado's Forests: Meeting the Challenge of Dead and at-Risk Trees. 2017. Available online: https://csfs.colostate. edu/media/sites/22/2018/01/2017_ForestHealthReport_FINAL.pdf (accessed on 1 May 2021).

32. Abrams, J.B.; Huber-Stearns, H.R.; Bone, C.; Grummon, C.A.; Moseley, C. Adaptation to a landscape-scale mountain pine beetle epidemic in the era of networked governance: The enduring importance of bureaucratic institutions. Ecol. Soc. 2017, 22, 22. [CrossRef]

33. Breshears, D.D.; Cobb, N.S.; Rich, P.M.; Price, K.P.; Allen, C.D.; Balice, R.G.; Romme, W.H.; Kastens, J.H.; Floyd, M.L.; Belnap, J.; et al. Regional vegetation die-off in response to global-change-type drought. Proc. Natl. Acad. Sci. USA 2005, 102, 15144-15148. [CrossRef]

34. Kleinman, S.J.; DeGomez, T.E.; Snider, G.B.; Williams, K.E. Large-scale piñon ips (Ips confusus) outbreak in southwestern United States tied with elevation and land cover. J. For. 2012, 110, 194-200.

35. USDA Forest Service US Forest Service Forest Health Protection Mapping and Reporting. 2021. Available online: https: / / data.nal.usda.gov / dataset/forest-health-protection-mapping-and-reporting (accessed on 1 May 2021).

36. Vogelmann, J.; Tolk, B.; Zhu, Z. Monitoring forest changes in the southwestern United States using multitemporal Landsat data. Remote Sens. Environ. 2009, 113, 1739-1748. [CrossRef] 
37. Fellin, D.G.; Dewey, J.E. Western spruce budworm. In Forest Insect and Disease Leaflet; USDA Forest Service: Washington, DC, USA, 1982

38. Tiffany, B.J. The Impact of Administrative Partitioning on the Regional Effectiveness of Forest Pest Management in Protected Area-Centered Ecosystems. Master's Thesis, Northern Arizona University, Flagstaff, AZ, USA, 2019.

39. Bernard, H.R. Research Methods in Anthropology, 4th ed.; AltaMira Press: Oxford, UK, 2006.

40. Thomas, D.R. A general inductive approach for analyzing qualitative evaluation data. Am. J. Eval. 2006, 27, 237-246. [CrossRef]

41. Bernard, H.R. Research Methods in Cultural Anthropology: Qualitative and Quantitative Approaches, 5th ed.; Altamira Press: New York, NY, USA, 2011.

42. QSR International. NVivo Qualitative Data Analysis Software, version 10 [software]; QSR International: Burlington, MA, USA, 2018.

43. Miles, M.B.; Huberman, A.M.; Saldaña, J. Qualitative Data Analysis: A Methods Sourcebook; Sage Publications, Inc.: Thousand Oaks, CA, USA, 2014.

44. Dillman, D.A. Procedures for Conducting Government-Sponsored Establishment Surveys: Comparisons of the Total Design Method (TDM), a Traditional Cost-Compensation Model, and Tailored Design. In Proceedings of the American Statistical Association, Second International Conference on Establishment Surveys, Buffalo, NY, USA, 17-21 June 2000; pp. 343-352. Available online: https://ww2.amstat.org/meetings/ices/2000/proceedings/S15.pdf (accessed on 12 June 2021).

45. Hershdorfer, M.E.; Fernandez-Gimenez, M.; Howery, L.D. Key attributes influence the performance of local weed management programs in the southwest United States. Rangel. Ecol. Manag. 2007, 60, 225-234. [CrossRef]

46. Pagano, M.; Gauvreau, K. Principles of Biostatics; Duxbury: Pacific Grove, CA, USA, 2020; p. 525.

47. Stortz, S. Participatory Analysis in Natural Resource Management: Legitimacy, Learning, and the Production of Actionable Science. Master's Thesis, Northern Arizona University, Flagstaff, AZ, USA, 2014.

48. Herrera, M.; Blasco, J.; Venegas, J.; Barba, R.; Doblas, A.; Marquez, E. Mouth occlusion pressure (P0.1) in acute respiratory failure. Intensiv. Care Med. 1985, 11, 134-139. [CrossRef]

49. Corbin, J.; Strauss, A. Basics of Qualitative Research: Techniques and Procedures for Developing Grounded Theory; Sage: Thousand Oaks, CA, USA, 2008.

50. Gallemore, C.; Di Gregorio, M.; Moeliono, M.; Brockhaus, M.; Prasti, H.R.D. Transaction costs, power, and multi-level forest governance in Indonesia. Ecol. Econ. 2015, 114, 168-179. [CrossRef]

51. Six, D.; Biber, E.; Long, E. Management for mountain pine beetle outbreak suppression: Does relevant science support current policy? Forests 2014, 5, 103-133. [CrossRef]

52. Jenkins, M.J.; Hebertson, E.G.; Munson, A.S. Spruce Beetle Biology, Ecology and Management in the Rocky Mountains: An Addendum to Spruce Beetle in the Rockies. Forests 2014, 5, 21-71. [CrossRef]

53. Malhotra, D.; Lumineau, F. Trust and collaboration in the aftermath of conflict: The effects of contract structure. Acad. Manag. J. 2011, 54, 981-998. [CrossRef]

54. Krueger, E.L. A transaction costs explanation of inter-local government collaboration. In Proceedings of the National Public Management Research Conference, Los Angeles, CA, USA, 29 September-1 October 2005.

55. McGinley, M.J.; Turk, A.; Bennett, D. Design criteria for public emergency warning systems. In Proceedings of the 3rd International Conference on Information Systems for Crisis Response and Management, Newark, NJ, USA, 14-17 May 2006 ; pp. 279-300.

56. Beier, P.; Hansen, L.J.; Helbrecht, L.; Behar, D. A how-to guide for coproduction of actionable science. Conserv. Lett. 2017, 10, 288-296. [CrossRef]

57. USFS (United States Forest Service). Forest Health Technology Aviation Team; Forest Health Protection: Fort Collins, CO, USA, 2014. 